Verhaak, P.F.M., Prins, M.A., Spreeuwenberg, P., Draisma, S., Balkom, T.J.L.M. van, Bensing, J.M., Laurant, M.G.H., Marwijk, H.W.J. van, Meer, K. van der, Penninx, B.W.J.H. Receiving treatment for common mental disorders. General Hospital Psychiatry: 2009, 31(1), 46-55

\begin{tabular}{|l|l|}
\hline Postprint Version & 1.0 \\
\hline Journal website & $\underline{\text { http://dx.doi.org/10.1016/j.genhosppsych.2008.09.011 }}$ \\
\hline Pubmed link & $\underline{\text { http://www.ncbi.nlm.nih.gov/pubmed/19134510 }}$ \\
\hline DOI & $10.1016 /$ j.genhosppsych.2008.09.011 \\
\hline
\end{tabular}

This is a NIVEL certified Post Print, more info at http://www.nivel.eu

\title{
Receiving treatment for common mental disorders
}

Peter F.M. VerhaAk Ph.D. ${ }^{\text {A, , }}$, Marijn A. Prins M.A. ${ }^{\text {A }}$, Peter SPreeuwenberg M.A. ${ }^{\text {A }}$, STASJA DRAISMA M.A. ${ }^{\mathrm{B}}$, TON J.L.M. VAN BALKOM M.D. ${ }^{\mathrm{B}}$, JOZIEN M. BENSING PH.D. ${ }^{\mathrm{A}}$, MiRANDA G.H. LAURANT PH.D. ${ }^{\mathrm{C}}$, HARM W.J. VAN MARWIJK M.D. ${ }^{\mathrm{D}}$, KLAAS VAN DER MEER M.D. ${ }^{\mathrm{E}}$ AND BRENDA W.J.H. PENNINX PH.D. ${ }^{\mathrm{B}, \mathrm{F}, \mathrm{G}}$

aNIVEL, Netherlands Institute for Health Services Research, 3500BH Utrecht, The Netherlands

bDepartment of Psychiatry, EMGO Institute, Institute for Neurosciences, VU University Medical Center, Amsterdam, The Netherlands

cCentre for Quality of Care Research, Radboud University Nijmegen Medical Center, Nijmegen, The Netherlands

dDepartment of General Practice, VU University Medical Center, Amsterdam, The Netherlands

eDepartment of General Practice, University Medical Center Groningen, Groningen, The Netherlands

fDepartment of Psychiatry, Leiden University Medical Center, Leiden, The Netherlands gDepartment of Psychiatry, University Medical Center Groningen, Groningen, The Netherlands

\section{AbSTRACT}

Objective: Anxiety and depressive disorders are widely prevalent, but patients are only treated in a minority of cases. In this study, the explanation of receiving mental health treatment is sought in predisposing and enabling characteristics and indicators for objective and self-perceived need.

Methods: Cross-sectional analysis of data collected in the Netherlands Study of Depression and Anxiety (NESDA) among 743 persons with an anxiety and/or depression diagnosis as assessed by the CIDI. Receipt of mental health treatment was assessed in the face-to-face interview, as well as indicators of predisposing and enabling factors and variables evaluating need for care.

Results: Of the total sample, 57\% received treatment in the past 6 months in the general practice setting (50\%) or the mental health care setting (14\%). Younger patients, patients who evaluated their providers better on communicative abilities and patients who perceived mental health problems themselves had greater odds of having professional mental health contacts in the primary care setting. Confidence in professional help and higher severity of mental problems were associated with greater odds of having specialized mental health care.

Conclusion: Receiving help for common mental disorders depends not only on the objective need of the patient but also at least as much on the patients' own recognition that their problems have a mental health origin. Furthermore, in primary care especially, the patients' judgment of their providers' affective 
Verhaak, P.F.M., Prins, M.A., Spreeuwenberg, P., Draisma, S., Balkom, T.J.L.M. van, Bensing, J.M., Laurant, M.G.H., Marwijk, H.W.J. van, Meer, K. van der, Penninx, B.W.J.H. Receiving treatment for common mental disorders. General Hospital Psychiatry: 2009, 31(1), 46-55

abilities may be decisive for being treated. For receiving specialized care, patients are also directed by their confidence in professional help.

\section{INTRODUCTION}

The most common mental disorders in the general community are depressive and anxiety disorders. A worldwide WHO study [1] showed a considerable 1-year prevalence range across countries, from $4.3 \%$ to $26.4 \%$. But at each of the 14 sites involved, anxiety disorders (2.4-18.2\%) and depressive disorder (1.7-9.8\%) ranked in the first two places. Comparable figures were replicated in the European Study of the Epidemiology of Mental Disorders [2], the Australian National Survey of Mental Health and Well-being [3], the US National CoMorbidity Study [4] and the Dutch NEMESIS study [5].

Many depressive and anxiety disorders are presented by somatic symptoms, which is seen as a reason for not recognizing these disorders [6]. Consequently, many of these disorders remain untreated. In the Dutch population-wide survey of 1996 [5], only 34\% of those with at least one mental health disorder reported some form of care (including informal care); $27 \%$ had been treated in primary care and $16 \%$ in ambulatory or residential mental health care. Kessler et al. [7] reported that in the US less than $40 \%$ of those with serious mental illness received treatment [7]. In the European study [8], 26\% of those with a diagnosis of mental disorder did consult a formal health service for their mental health. In the WHO study [1] and [9] mentioned above, $1 \%$ (Nigeria) to 15\% (USA) of all cases received help. Taking only severe cases, the range of received treatment varied between 15\% (Lebanon) and 65\% (Spain) with a median of 51\% (Netherlands, USA).

Up to now, epidemiological studies have provided a limited understanding of the patient characteristics, related to treatment reception. Women, 35-55 year olds, people in cities, single persons and unemployed or disabled persons, patients with more severe disorders and patients with comorbidity were more likely to access some kind of care [5], [10], [11] and [12].

Attention has been focused on clinical, socioeconomic and socio-demographic characteristics. Little attention has been paid to psychological factors such as beliefs, values and personality as determinants of help-seeking behavior. Jorm et al. [13] and [14] called attention to a widespread misunderstanding among the public about the prognosis, benefits and risks of mental health treatments which might easily constitute a barrier to help-seeking. Similarly, little attention has been paid to the patient's perspective. Clinical need has always been assessed by means of standardized instruments that can be characterized as symptom inventories. The need for care - as the patient perceives it - remained out of focus. In the same realm are patients' earlier experiences with mental health care, as these might also explain current help-seeking behavior [15]. Negative experiences in the past may prevent future help-seeking behavior, and thus treatment, as well.

This paper adds to this deficit in the literature by applying the behavioral model of Andersen et al. [16] and [17]. This model distinguishes three groups of determinants for the use of services: determinants that contribute (a) to people's disposition to use services, (b) factors that enable the use of services and (c) factors that determine the need for care. Also, the interaction between several determinants of the help-seeking process can be studied within the behavioral model of Andersen.

Among the Predisposing characteristics, demographic factors and personality characteristics are counted as well as people's attitudes, beliefs and values regarding mental health care. The Enabling factors indicate availability of care and include geographical (distance) and financial (insurance, income) access to institutions. The Need for care can be divided into need for care from the patient's perception (the perceived or subjective need for care) and the need for care as assessed by the clinician (clinical or objective need for care). Clinical need for care has a number of indicators: the diagnosis, severity, presence of comorbidity and recurrence. 
Verhaak, P.F.M., Prins, M.A., Spreeuwenberg, P., Draisma, S., Balkom, T.J.L.M. van, Bensing, J.M., Laurant, M.G.H., Marwijk, H.W.J. van, Meer, K. van der, Penninx, B.W.J.H. Receiving treatment for common mental disorders. General Hospital Psychiatry: 2009, 31(1), 46-55

Originally, the model was intended to evaluate the 'equity' of health care systems.

Equitable access is defined by Andersen [17] as "occurring when demographic and need variables account for most of the variance in utilization”. Analyzing use of services within the broader context of need, predisposing and enabling factors makes it possible to detect imperfections within the functioning of the mental health care system.

In this paper, we will look for patient characteristics that increase the chances of receiving treatment for the most prevalent mental disorders: depressive and anxiety disorders. We will apply Andersen's model with special attention for psychological characteristics and the patient's perspective among the predisposing characteristics.

Our research question is: to what degree is the use of mental health services by persons with depressive and/or anxiety disorders explained by

1. predisposing characteristics (socio-demographics, personality, beliefs about mental health care, evaluation of mental health care received in the past);

2. enabling characteristics (availability of facilities, access to facilities, income); and

3. need characteristics (self-perceived need, type and severity of disorder, psychiatric comorbidity, somatic comorbidity)?

\section{SUBJECTS AND METHOD}

\subsection{Design}

Data on the use of health services were collected in the Netherlands Study of Depression and Anxiety (NESDA, http://www.nesda.nl). NESDA is a multi-centre study designed to examine the long-term course and consequences of anxiety and depressive disorders. Within the NESDA framework, 743 patients with a $D S M-I V$ diagnosis of mood or anxiety disorder in the past 6 months were recruited in primary care settings. For a more detailed description of this study, see Ref. [18].

This primary care sample was selected from adult patients - aged between 18 and 65 years - who visited their GP in the past 4 months, irrespective of the reason for their visit. Clinical inclusion criteria were $D S M-I V$ anxiety or depression diagnoses which are summed up in Table 1.

\section{[TABLE 1]}

Excluded were patients with a primary diagnosis of psychotic disorder, obsessive compulsive disorder, bipolar disorder or severe addiction disorder, since the course and care pathways of these patients will be determined largely by the primary disorder which is not a subject of the NESDA study. A second exclusion criterion was not being fluent in Dutch.

Primary care patients were recruited from the practices of 65 general practitioners (GPs) in the vicinity of the field sites (Amsterdam, Groningen, Leiden). In the Netherlands, all patients are registered with a general practice. A three-stage screening procedure was used for the selection of respondents. Screening questionnaires were sent to a random sample of GP patients aged 18-65 years who had consulted the GP in the previous 4 months irrespective of the reason for consultation. The screening questionnaire consisted of the Kessler-10 list (K-10) [18] extended with five anxiety questions. The K-10 has been found to have good screening characteristics, especially for depressive disorders [19] and [20]. Compared to the K10, the extended K10 has a higher sensitivity and specificity for detecting both depressive and anxiety disorders [21]. Screen positives were approached for a short telephone screening interview, consisting of the CIDI-short-form sections for anxiety and depressive disorders. Those who fulfilled the study criteria and criteria for a current depressive or anxiety disorder during the telephone screening interview were invited to participate in the NESDA study. In addition, a random selection of the screen negatives was also invited to participate. 
Verhaak, P.F.M., Prins, M.A., Spreeuwenberg, P., Draisma, S., Balkom, T.J.L.M. van, Bensing, J.M., Laurant, M.G.H., Marwijk, H.W.J. van, Meer, K. van der, Penninx, B.W.J.H. Receiving treatment for common mental disorders. General Hospital Psychiatry: 2009, 31(1), 46-55

During the baseline measurement, a complete CIDI interview was completed together with other interviews and questionnaires, to be mentioned below.

A total of 23,750 screening questionnaires were sent out by primary care physicians, 10,774 of which (45\%) were returned. Those returning the screener were more likely to be female ( $59.3 \%$ vs. $50.0 \%, P<.001$ ) and older ( 44.4 vs. 39.0 years, $P<.001$ ) compared to those not returning the screener. With this three-stage screening procedure, 743 participants with a 6month depressive or anxiety disorder were recruited in the primary care setting. The complete sampling history is given in Fig. 1.

\section{[FIGUUR 1]}

\subsection{Measures}

\subsubsection{Dependent variable: use of mental health services}

Mental health treatment was measured by means of the Perceived Need for Care Questionnaire (PNCQ) [22]. The PNCQ is a structured interview by which the use of health care services during the past 6 months can be carefully assessed. The respondents report whether they had any contacts during the past 6 months with a general practitioner, a medical specialist or a company doctor because of mental health problems and/or whether they had any contacts with a social worker, a psychologist working in primary care, a psychiatrist, a psychotherapist, an institution for ambulatory mental health care or an institution for addiction problems.

\subsubsection{Independent variables}

\subsubsection{Predisposing characteristics}

Detailed socio-demographic data, including age, gender and ethnicity, were collected. Socioeconomic information was collected by asking about education level. The patient's confidence in mental health care, considered to be a relevant belief, was measured with two items measuring "confidence in professional help" (Cronbach's alpha=.78), two items measuring "confidence in lay help" (Cronbach's alpha=.46) and one item: "psychological problems are best kept to yourself". Personality was measured with the NEO personality questionnaire, a 60 -item questionnaire which measures the five personality domains neuroticism, extraversion, agreeableness, conscientiousness and openness to experience [23]. NESDA included the QUOTE (QUality Of care Through the Eyes of the patient) instrument to measure the evaluation of received care for depression and anxiety [24]. The 19-item questionnaire consists of evaluations of provider's past performances regarding emotional support (three items, Cronbach's alpha=.77), patient centeredness (four items, Cronbach's alpha=.75), quality of care received (three items, Cronbach's alpha=.79), information (two items, Cronbach's alpha=.62) and advice received on self-help (two items, Cronbach's alpha=.73).

\subsubsection{Enabling characteristics}

A high urbanization level is considered an indicator for enabling resources because the supply of institutions and providers is higher. Accessibility, evaluated by the item "I could make an appointment within two days" from the QUOTE instrument (see above), is considered an enabling resource. Income of the respondent was assessed during the interview.

\subsubsection{Needs}

A distinction is made between the subjective and objective need for care. Subjective need is the patient's perception of having an emotional problem. This was measured during the 
Verhaak, P.F.M., Prins, M.A., Spreeuwenberg, P., Draisma, S., Balkom, T.J.L.M. van, Bensing, J.M., Laurant, M.G.H., Marwijk, H.W.J. van, Meer, K. van der, Penninx, B.W.J.H. Receiving treatment for common mental disorders. General Hospital Psychiatry: 2009, 31(1), 46-55

PNCQ interview (see above), in that the patient expressed in the initial question whether he or she had experienced any psychological problem during the past 6 months. Objective need for care was indicated by $D S M-I V$ diagnoses, severity measures and presence of somatic and psychiatric co-morbidity. The 6-month diagnoses of depression and anxiety disorders (see Table 1 for all included diagnoses) were established with the CIDI psychiatric interview (WHO version 2.1) which classifies diagnoses according to the $D S M-I V$ criteria (American Psychiatric Association, 2001). Specially trained clinical research staff conducted the CIDI interviews. The life-time CIDI allows for the determination of the history, recency, duration and age of onset of episodes.

The severity of depressive symptoms was measured with the 30-item Inventory of Depressive Symptoms, self-report version (IDS-SR) [25]. The severity of generalized anxiety and panic symptoms was measured using the validated Beck Anxiety Inventory (BAI), a 21-item scale [26].

Psychiatric co-morbidity was measured by counting the number of 6-month CIDI diagnoses. Thus, only the co-morbidity of several depressive and anxiety disorders was measured, as other psychiatric disorders were not assessed in our interview and some of them were even explicitly excluded (see above).

In order to measure somatic co-morbidity, an inventory of somatic disease was constructed with detailed questions about presence of and treatment received for 20 different chronic conditions. The number of different chronic conditions for which medical treatment was received is used as an index of somatic co-morbidity.

\subsection{Analytic strategy}

Our study sample consists of the 743 persons from the primary care sample who fulfilled the criteria for a $D S M-I V$ diagnosis of anxiety or depression. Based on self-reporting in the PNCQ, this sample was divided into persons who had received some kind of treatment (information, medication, counseling, advice, practical support) from any care provider during the last 6 months vs. persons who had not.

Univariate tests ( $\chi^{2}$ and $t$-test for independent samples) were performed on each of the predisposing, enabling and need determinants described above. The same procedure was followed for persons discussing their psychological problems within primary care vs. those who did not, and persons discussing their psychological problems within specialized care vs. those who did not.

As the 743 respondents are nested within 65 GPs, multilevel stepwise logistic regression (software MLwiN 2.02, estimation procedure PQL, second order with unconstrained level 1 variance), involving all determinants with a significant effect $(P<.05)$ in the univariate tests, was carried out. First, the relevant predisposing characteristics were entered at the level of the individual respondent, following which enabling and need variables were added in the second and third steps.

\section{RESULTS}

Table 1 shows the composition of psychopathology in the study sample. Almost $80 \%$ of the persons suffered from anxiety disorder and a smaller proportion of nearly $60 \%$ had had one or more depressive disorders during the past 6 months. More than one third of the sample showed co-morbidity of depressive and anxiety disorder during the past 6 months.

\subsection{Use of mental health services}

Table 2 presents the use of services for the mental health problems as reported by the respondents. 
Verhaak, P.F.M., Prins, M.A., Spreeuwenberg, P., Draisma, S., Balkom, T.J.L.M. van, Bensing, J.M., Laurant, M.G.H., Marwijk, H.W.J. van, Meer, K. van der, Penninx, B.W.J.H. Receiving treatment for common mental disorders. General Hospital Psychiatry: 2009, 31(1), 46-55

\section{[TABLE 2]}

About half of the study sample had had contacts within primary care concerning psychological problems in the past 6 months, especially with their GPs (41.7\%). A total of $13.6 \%$ had had contacts with specialized mental health care. Another $13.6 \%$ had had contacts with more specialized medical doctors, especially company doctors. A total of $43.1 \%$ reported having no contact at all during which mental health problems were discussed.

\subsection{Determinants of mental health treatment}

The first two columns of Table 3 show the characteristics of patients who received mental health treatment from any provider vs. patients who did not. Patients who received treatment were younger, had more confidence in professional help for mental health problems and scored higher on neuroticism than persons who did not $(P<.05)$. They had also had better experiences with providers in the past: they evaluated the emotional support, patient centeredness and quality of care received on those occasions better and they had received better advice on self-help.

\section{[TABLE 3]}

There were no differences between the two groups regarding any of the enabling factors, but there were outspoken differences on all the determinants indicating need. Patients who received treatment had more and more severe disorders $(P<.000)$. The effect of perceived need is clear as well: among those who did not receive any treatment, about one quarter denied having any psychological problems. The number of somatic diseases reported by the patient was equal in both groups.

The same trends are more or less present when differences between those receiving treatment in primary care are compared with those not receiving such treatment (Table 3: column 4 vs. 3).

As far as receiving treatment by a specialist mental health professional is concerned (column 6 vs. 5), some other determinants make a significant difference: those receiving treatment more often have an anxiety disorder and have less confidence in help from relatives or friends when mental issues are at stake. On the other hand, the evaluation of past performance of providers did not make any difference between patients receiving and not receiving specialized mental health care.

Finally, the significant differences between treated and not treated patients were tested in a multilevel logistic regression analysis (see Table 4). The same tests were done for the significant differences between treatment in primary care and no treatment in primary care (Table 5), and between receiving and not receiving specialized mental health care (Table 6).

\section{[TABLE 4]}

\section{[TABLE 5]}

\section{[TABLE 6]}

In all three analyses, no significant effects could be found at the doctor's level, indicating that the help-seeking behavior was not very different in patients listed at different GP practices. Thus, effects at a patient level, reported below, cannot be attributed to systematic differences between the doctors in our study sample.

Patients who received treatment in either primary or specialized settings tended to be younger, had more positive evaluations regarding provider's emotional support and patient centeredness, and had a more outspoken problem perception themselves. Initially, those 
Verhaak, P.F.M., Prins, M.A., Spreeuwenberg, P., Draisma, S., Balkom, T.J.L.M. van, Bensing, J.M., Laurant, M.G.H., Marwijk, H.W.J. van, Meer, K. van der, Penninx, B.W.J.H. Receiving treatment for common mental disorders. General Hospital Psychiatry: 2009, 31(1), 46-55

patients tended to endorse more positive confidence about professional help, but after the introduction of evaluations of past experiences, this relationship disappeared. They tended to be more neurotic as well, but after the introduction of clinical need variables, this relationship again disappears. The various clinical need variables all had a significant difference initially, but lost their significant effect after controlling for each other and for patients' perception of their own mental health.

When treatment is specified (i.e., primary care and specialized mental health care), two different components can be distinguished. First, in primary care (Table 5), the evaluation of past performance matters, while confidence in professional help was not a significant factor even in univariate comparisons. As far as need is concerned, the patient's own perceived need is of decisive importance for help-seeking in primary care. Second, in the case of specialized mental health care (Table 6), positive confidence in professional help and negative confidence in lay help are positively correlated to contacts in specialized mental health care. Reported evaluations of past experiences with care providers bear no relationship. The critical need factor for help-seeking in specialized mental health care is the number of psychiatric diagnoses, whereas patients' perception of having a mental health problem is not an essential factor.

\section{DISCUSSION}

\subsection{Summary of main findings}

Our study indicated that $57 \%$ of patients with a diagnosis of anxiety or depression who recently visited their GP had received professional treatment, mostly (50\%) in primary care, especially with their GP. Fourteen percent of them had contacted a specialist mental health care professional and another 14\% reported having received treatment from another kind of medical doctor, mostly a company doctor. Forty-three percent of these patients had not had any professional contact regarding their mental distress.

The odds of mental health treatment in primary care were higher for younger people, for people with more positive evaluations of their mental health provider and for people who perceived themselves as having a mental problem. The odds of treatment in specialized mental health care were dependent on confidence in professional help and distrust of lay help, together with a higher objective need, as was indicated by more psychiatric diagnoses. Enabling factors did not have any effect on receiving treatment. Neither the income of the patients, the perceived accessibility of services nor the factual presence of services made any difference between the respondents receiving treatment and those who did not. This may be typical for the Dutch situation, where access to care is not dependent on income, and geographically within the reach of everyone.

\subsection{Contribution to existing knowledge}

On the whole, the results tie in with earlier reported knowledge about need and sociodemographic predictors for treatment: patients who are more in need, expressed by severity and co-morbidity (number of mental disorders), received more treatment in both primary care and specialized mental health care. Relatively new in this respect is the impact of subjective need: patients' own perception of having a psychological problem proved to be the most strongly associated in multivariate analysis with receiving any treatment and primary care treatment. In specialized mental health care, this own perception is less decisive, probably because of the higher severity of the disorders of the patients receiving specialized mental health care. The higher probability that younger adults will seek treatment is also replicated in this study.

Although we found a slight overrepresentation of women, employed people and people from large cities among those who received primary care treatment or any treatment at all, these differences, reported in the Introduction section, were not significant in our study. 
Verhaak, P.F.M., Prins, M.A., Spreeuwenberg, P., Draisma, S., Balkom, T.J.L.M. van, Bensing,

J.M., Laurant, M.G.H., Marwijk, H.W.J. van, Meer, K. van der, Penninx, B.W.J.H. Receiving

treatment for common mental disorders. General Hospital Psychiatry: 2009, 31(1), 46-55

New in our study is the relationship between patients' judgments about provider's emotional support, patient centeredness, information and advice on the one hand and being treated on the other. This judgment is consistently more positive in the case of patients who report having received treatment in primary care; this difference is not found between patients who have received treatment in specialized mental health care and those who have not. Treatment in primary care appears more dependent on earlier experiences with the affective support the patient expects than on the decision to consult specialized mental health care does. The latter decision is in turn more strongly related to the patients' confidence in professional help and their distrust of lay help.

The impact of the GP's affective support and patient centeredness on the detection and treatment of mental disorders has been demonstrated earlier [27], [28], [29] and [30]. New on the other hand is the consistent qualification of those who receive treatment as being more neurotic than those who do not. This, however, seems to be explained by the larger clinical need of the former group, because the effect disappears after introducing the need factors.

\subsection{Methodological considerations and limitations}

Receiving treatment for mental health problems was measured by the respondent's affirmative answer to the question whether "he/she had discussed their problems with a GP, a psychiatrist, a psychologist, etc.” It is the patient's perception of having received some treatment. Comparable indicators for treatment have been used in the studies cited in the Introduction [2], [5] and [7].

The mental health status of the respondents was established using the CIDI interview. In this respect, the methodology is comparable with the earlier studies as well. One disadvantage in the NESDA study, in terms of sampling, is the geographic emphasis of the three study centers in the Netherlands. For budgetary reasons, GP practices around the three participating university centers (three large cities in urbanized areas) were invited to supply the sampling frames. As a result, patients from strongly urbanized areas were overrepresented. Because of this, variation in degree of urbanization is too small to make this factor a significant determinant of mental health treatment.

We studied the chances of being treated among a population that had had at least one GP contact during the past 4 months. Patients without any professional contact (and so, by definition without any treatment) are left out of consideration. Therefore, our estimate about the number of treated patients is an overestimation of the actual number. However, samples drawn from the general population in the same NESDA survey, who were assessed with the same instruments, show comparable figures and relationships as those presented here. Therefore, we conclude that our sampling policy has not caused large distortions.

A last, but important limitation of the current data is its cross-sectional character. Selfperceived need and evaluations of providers' emotional support and patient centeredness are presented as 'determinants' of help-seeking behavior, but were in fact all measured in the same interview. Consequently, causal inferences cannot be drawn from our results. The analyses presented here are mainly exploratory by character as well. However, as NESDA is a 10-year longitudinal research program, we will in the future be able to test a real causal relationship over time, driven by the hypothesis that patients who report positive experiences about their provider in the past will recover better in the future than patients with negative experiences.

\subsection{Discussion}

Returning to Andersen's evaluation model, we can make the following comments. Getting help for common mental disorders does not depend only on the objective need of the patient, although patients with more disorders and more severe disorders have better chances of receiving treatment. Just as important as the objective need, as assessed by clinical interviews and instruments, is the patients' own recognition of their problem as being a mental health problem. When all patients receiving treatment are considered, this subjective need outweighs even the indicators for objective need. Only when we focus on 
Verhaak, P.F.M., Prins, M.A., Spreeuwenberg, P., Draisma, S., Balkom, T.J.L.M. van, Bensing, J.M., Laurant, M.G.H., Marwijk, H.W.J. van, Meer, K. van der, Penninx, B.W.J.H. Receiving treatment for common mental disorders. General Hospital Psychiatry: 2009, 31(1), 46-55

patients receiving specialized mental health care does objective need (indicated by the number of psychiatric diagnoses) overrule subjective need.

But it is certainly not only the patients' need for help that determines the help-seeking process. In primary care especially, the patient's judgment of providers' affective abilities may be decisive for seeking help or not. In specialized care, patients are directed by their confidence in professional help as well.

\subsection{Clinical implications}

These results have certain clinical implications. First and foremost, patients' help-seeking behavior is directed by their expectations about their health care providers. When they have experienced emotional support and when they have felt understood and well advised on earlier occasions, they will tend to present their mental health problems to a professional. When they did not, they may abstain from seeking help.

Second, health care providers in general should be aware of the fact that older patients and less neurotic patients (i.e., patients who might not be very explicit about possible mental distress) will have a greater tendency to be silent about possible feelings of distress than more neurotic patients.

Third, patients will be more inclined to be referred to specialized mental health care when they have a positive perception of the help psychologists or psychiatrists can provide. This is an assignment for mental health services in general to work on a better image, and for all individual mental health workers specifically to engender such an image. In this respect, each mental health care provider who is initially seen by the patient with a request for mental help either directly or through another medical referrer — mostly the GP — has a major responsibility. Professionals should be aware of the image of mental health care as constructed by the patients. The same professionals might play an important role in this image building.

\section{REFERENCES}

[1] The WHO World Mental Health Survey Consortium, Prevalence, severity and unmet need for treatment of mental disorders in the World Health Organization World Mental Health Surveys, JAMA 291 (21) (2004), pp. 2581-2590.

[2] J. Alonso, M.C. Angermeyer, S. Bernert, R. Bruffaerts, T.S. Brugha and H. Bryson et al., Prevalence of mental disorders in Europe: results from the European Study of the Epidemiology of Mental Disorders (ESEMeD) project, Acta Psychiatr Scand 109 (s420) (2004), pp. 21-27.

[3] G. Andrews, W. Hall, M. Teesson and S. Henderson, The mental health of Australians, Mental Health Branch, Commonwealth Department of Health and Aged Care, Canberra (1999).

[4] R.C. Kessler, K.A. McGonagle, S. Zhao, C.B. Nelson, M. Hughes and S. Eshleman et al., Lifetime and 12-month prevalence of DSM-III-R psychiatric disorders in the United States, Arch Gen Psych 51 (1994), pp. 8-19.

[5] R.V. Bijl and A. Ravelli, Psychiatric morbidity, service use and need for care in the general population: results of the Netherlands Mental Health Survey and Incidence Study, Am J Public Health 90 (4) (2000), pp. 602-607.

[6] K. Barkow, R. Heun, T.B. Ustün, M. Berger, T. Bermejo and W. Gaebel et al., Identification of somatic and anxiety symptoms which contribute to the detection of depression in primary health care, Eur Psychiatry 19 (5) (2004), pp. 250-257.

[7] R.C. Kessler, P.A. Berglund, M.L. Bruce, R. Koch, E.M. Laska and P.J. Leaf et al., The prevalence and correlates of untreated serious mental illness, Health Serv Res 36 (6) (2001), pp. 987-1007.

[8] J. Alonso, M.C. Angermeyer, S. Bernert, R. Bruffaerts, T.S. Brugha and H. Bryson et al., Use of mental health services in Europe: results from the European Study of the Epidemiology of Mental Disorders (ESEMeD) project, Acta Psychiatr Scand 109 (s420) (2004), pp. 47-54. 
Verhaak, P.F.M., Prins, M.A., Spreeuwenberg, P., Draisma, S., Balkom, T.J.L.M. van, Bensing, J.M., Laurant, M.G.H., Marwijk, H.W.J. van, Meer, K. van der, Penninx, B.W.J.H. Receiving treatment for common mental disorders. General Hospital Psychiatry: 2009, 31(1), 46-55

[9] P.S. Wang, S. Aguilar-Gaxiola, J. Alonso, M.C. Angermeyer, G. Borges and E.J. Bromet et al., Use of mental health services for anxiety, mood, and substance disorders in 17 countries in the WHO world mental health surveys, Lancet 370 (9590) (2007), pp. 807808.

[10] P. Bebbington, H. Meltzer, T.S. Brugha, M. Farrell, R. Jenkins and C. Ceresa et al., Unequal access and unmet need: neurotic disorders and the use of primary care services, Psychol Med 30 (2000), pp. 1359-1367.

[11] R.C. Bland, S.C. Newman and H. Orn, Help-seeking for psychiatric disorders, Can J Psychiatry 42 (1997), pp. 935-941.

[12] R.A. Parslow and A.F. Jorm, Who uses mental health services in Australia? An analysis of data from the national survey of mental health and well-being, Aust NZ J Psychiat 34 (6) (2000), pp. 997-1008.

[13] A.F. Jorm, M. Angermeyer and H. Katschnig, Public Knowledge of and attitudes to mental disorders: a limiting factor in the optimal use of treatment services. In: G. Andrews and S. Henderson, Editors, Unmet need in psychiatry. Problems, resources, responses, Cambridge University Press, Cambridge (2000).

[14] A.F. Jorm, Mental health literacy. Public knowledge and beliefs about mental disorder, Br J Psychiatry 177 (2000), pp. 396-401.

[15] M.A. Prins, P.F.M. Verbaak, K. vd Meer and J.M. Bensing, Health beliefs and perceived need of mental health care for anxiety and depression-the patient's perspective explored. Clin Psychol Rev 28 (2008), pp. 1038-1058.

[16] R. Andersen and J. Newman, Societal and individual determinants of medical care utilization in the United States, Millbank Mem Fund Q 51 (1973), pp. 95-124.

[17] R.M. Andersen, Revisiting the behavioral model on access to medical care: does it matter?, J Health Soc Behav 36 (1995), pp. 1-10.

[18] B.W.J.H. Penninx, A.T.F. Beekman, J.H. Smit, F.G. Zitman, W.A. Nolen and P. Spinhoven et al., The Netherlands Study of Depression and Anxiety (NESDA): Rationale, Objectives and Methods, Int J Methods Psychiatr Res 17 (3) (2008), pp. 121-140.

[19] R.C. Kessler, P.R. Barker, L.J. Colpe, J.F. Epstein, J.C. Gfroerer and E. Hiripi et al., Screening for serious mental illness in the general population, Arch Gen Psychiatry, 60 (2003), pp. 184-189.

[20] T.A. Furukawa, R.C. Kessler, T. Slade and G. Andrews, The performance of the K6 and K10 screening scales for psychological distress in the Australian National Survey of Mental Health and Well-Being, Psychol Med 33 (2003), pp. 357-362.

[21] Donker T, Comijs HC, Cuijpers P, Terluin B, Nolen WA, Zitman FG, Penninx BW. The validity of the extended K10 screening scale for depressive and anxiety disorders [submitted for publication].

[22] G. Meadows, P. Burgess, E. Fossey and C. Harvey, Perceived need for mental health care, findings from the Australian National Survey of Mental Health and Well-Being, Psychol Med 30 (2000), pp. 645-656.

[23] P.T. Costa and R.R. McCrae, Domains and facets: hierarchical personality assessment using the revised NEO personality inventory, J Pers Assess 64 (1995), pp. 21-50.

[24] H.J. Sixma, J.J. Kerssens, C.V. Campen and L. Peters, Quality of care from the patients' perspective: from theoretical concept to a new measuring instrument, Health Expect 1 (1998), pp. 82-95.

[25] A.J. Rush, C.M. Gullian, M.R. Basco, R.B. Jarrett and M.M. Trivedi, The Inventory of Depressive Symptomatology (IDS). Psychometric properties, Psychol Med 26 (1996), pp. 477-486. View Record in Scopus | Cited By in Scopus (281)

[26] A.T. Beck, N. Epstein, G. Brown and R.A. Steer, An inventory for measuring clinical anxiety: psychometric properties, J Consult Clin Psychol 56 (1988), pp. 893-897.

[27] J.M. Bensing, M. vd Pasch and J.J. Kersens, Patient-directed gaze as a tool for discovering and handling psychosocial problems in general practice, J Nonverbal Behav 19 (4) (1995), pp. 223-242.

[28] J.N. Marks, D.P. Goldberg and V.F. Hillier, Determinants of the ability of general practitioners to detect psychiatric illness, Psychol Med 9 (1979), pp. 337-353.

[29] M.A.A. van der Pasch and P.F.M. Verhaak, Communication in general practice: recognition and treatment of mental illness, Patient Educ Couns 33 (2) (1998), pp. 97-112. 
Verhaak, P.F.M., Prins, M.A., Spreeuwenberg, P., Draisma, S., Balkom, T.J.L.M. van, Bensing, J.M., Laurant, M.G.H., Marwijk, H.W.J. van, Meer, K. van der, Penninx, B.W.J.H. Receiving treatment for common mental disorders. General Hospital Psychiatry: 2009, 31(1), 46-55

\section{nivel}

[30] P. Salmon, A. Ring, C.F. Dowrick and G.M. Humphris, What do general practice patients want when they present medically unexplained symptoms, and why do their doctors feel pressurized?, J Psychosom Res 59 (2005), pp. 255-262.

\section{TABLES EN FIGUUR}

Table 1.: Absolute number and percentage of $D S M-I V$ diagnoses (6-month recency) of included primary care patients $(N=743)$

\begin{tabular}{|l|l|l|}
\hline All psychopathology & $n$ & $\%$ \\
\hline Anxiety & 192 & $25.8 \%$ \\
\hline GAD & 277 & $37.3 \%$ \\
\hline Social phobia & 103 & $13.9 \%$ \\
\hline Panic without agoraphobia & 158 & $21.3 \%$ \\
\hline Panic with agoraphobia & 97 & $13.1 \%$ \\
\hline Agoraphobia without panic & 589 & $79.3 \%$ \\
\hline At least 1 anxiety disorder & & \\
\hline Depression & 185 & $24.9 \%$ \\
\hline Major depression single & 227 & $30.6 \%$ \\
\hline Major depression recurrent & 115 & $15.5 \%$ \\
\hline Dysthymia & 437 & $58.8 \%$ \\
\hline At least one depressive disorder & & 1.8 \\
\hline Mean $n$ of DSM-IV diagnoses & & $41.2 \%$ \\
\hline Anxiety without depressive disorder & & $20.7 \%$ \\
\hline Depressive disorder without anxiety & & $38.1 \%$ \\
\hline Comorbid depressive disorder and anxiety & & \\
\hline & & \\
\hline
\end{tabular}


Verhaak, P.F.M., Prins, M.A., Spreeuwenberg, P., Draisma, S., Balkom, T.J.L.M. van, Bensing, J.M., Laurant, M.G.H., Marwijk, H.W.J. van, Meer, K. van der, Penninx, B.W.J.H. Receiving treatment for common mental disorders. General Hospital Psychiatry: 2009, 31(1), 46-55

Fig. 1. Recruitment flow of NESDA respondents in the primary care setting.

I: screening questionnaire among GPpatients $(18-65$ yr) with GPcontact past 4 months

II: Phone screen among screen positives

III: T-0 of NESDA (among which: CIDI)

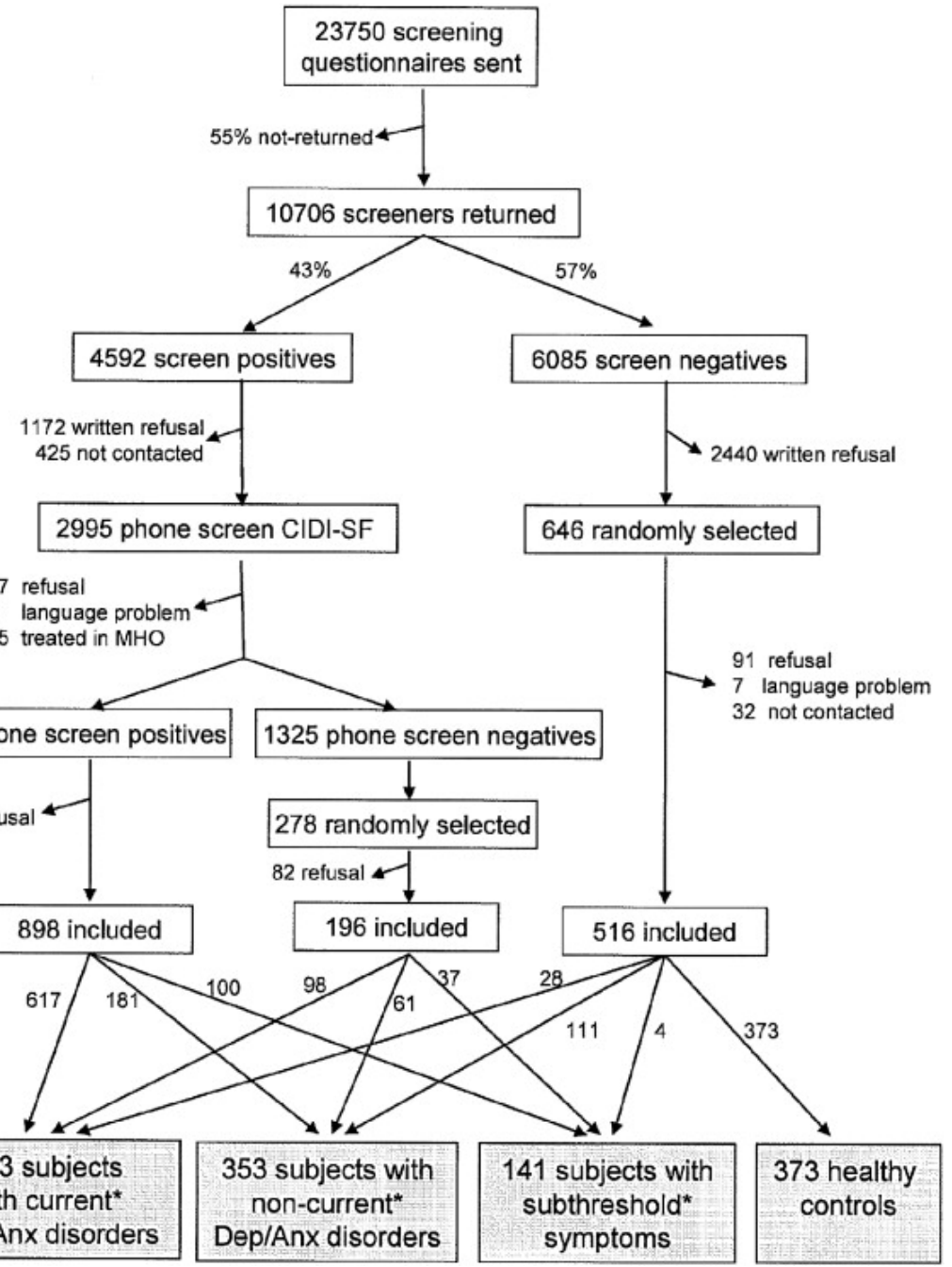


Verhaak, P.F.M., Prins, M.A., Spreeuwenberg, P., Draisma, S., Balkom, T.J.L.M. van, Bensing, J.M., Laurant, M.G.H., Marwijk, H.W.J. van, Meer, K. van der, Penninx, B.W.J.H. Receiving treatment for common mental disorders. General Hospital Psychiatry: 2009, 31(1), 46-55

Table 2.: Absolute number and percentage of professional help received by included primary care patients in the past 6 months $(N=743)$

\begin{tabular}{|l|l|l|}
\hline Professional help received & $n$ & $\%$ \\
\hline Primary care & 370 & $49.8 \%$ \\
\hline General practitioner & 310 & $41.7 \%$ \\
\hline Social work & 67 & $9.0 \%$ \\
\hline Primary care psychologist & 106 & $14.3 \%$ \\
\hline Psychiatric nurse & 8 & $1.1 \%$ \\
\hline Specialist mental health care & 101 & $13.6 \%$ \\
\hline Ambulatory mental health care & 39 & $5.2 \%$ \\
\hline Psychiatrist & 39 & $5.2 \%$ \\
\hline Psychotherapist & 29 & $3.9 \%$ \\
\hline Alcohol/drugs department & 7 & $0.9 \%$ \\
\hline Medical care & 101 & $13.6 \%$ \\
\hline & 18 & $2.4 \%$ \\
\hline Medical specialist & & \\
\hline Company doctor & 86 & $11.6 \%$ \\
\hline No treatment at all & 320 & $43.1 \%$ \\
\hline
\end{tabular}

Table 3.: Characteristics of patients with a mental disorder who received any treatment vs. no treatment, primary care treatment vs. no primary care treatment and specialized treatment vs. no specialized treatment

\begin{tabular}{|c|c|c|c|c|c|c|}
\hline & \multicolumn{2}{|c|}{$\begin{array}{l}\text { Receiving any } \\
\text { treatment }\end{array}$} & \multicolumn{2}{|c|}{$\begin{array}{l}\text { Receiving treatment in } \\
\text { primary care setting }\end{array}$} & \multicolumn{2}{|c|}{$\begin{array}{l}\text { Receiving treatment in } \\
\text { specialized mental } \\
\text { care setting }\end{array}$} \\
\hline & No & Yes & No & Yes & No & Yes \\
\hline$n$ & 320 & 423 & 373 & 370 & 642 & 101 \\
\hline \multicolumn{7}{|c|}{ Predisposing characteristics } \\
\hline Male & $31 \%$ & $28 \%$ & $31 \%$ & $27 \%$ & $29 \%$ & $31 \%$ \\
\hline $\begin{array}{l}\text { Age (mean } \\
\text { years; range: } \\
\text { 18-65) }\end{array}$ & 46.2 & 43.9 & 46.1 & 43.7 & 45.0 & 43.8 \\
\hline $\begin{array}{l}\% \text { Born in the } \\
\text { Netherlands }\end{array}$ & $86 \%$ & $89 \%$ & $86 \%$ & $90 \%$ & $89 \%$ & $83 \%$ \\
\hline$\%$ Low & $41 \%$ & $34 \%$ & $39 \%$ & $35 \%$ & $39 \%$ & $28 \%$ \\
\hline
\end{tabular}


Verhaak, P.F.M., Prins, M.A., Spreeuwenberg, P., Draisma, S., Balkom, T.J.L.M. van, Bensing, J.M., Laurant, M.G.H., Marwijk, H.W.J. van, Meer, K. van der, Penninx, B.W.J.H. Receiving treatment for common mental disorders. General Hospital Psychiatry: 2009, 31(1), 46-55

nivel

\begin{tabular}{|c|c|c|c|c|c|c|}
\hline & \multicolumn{2}{|c|}{$\begin{array}{l}\text { Receiving any } \\
\text { treatment }\end{array}$} & \multicolumn{2}{|c|}{$\begin{array}{l}\text { Receiving treatment in } \\
\text { primary care setting }\end{array}$} & \multicolumn{2}{|c|}{$\begin{array}{l}\text { Receiving treatment in } \\
\text { specialized mental } \\
\text { care setting }\end{array}$} \\
\hline & No & Yes & No & Yes & No & Yes \\
\hline \multicolumn{7}{|l|}{ education } \\
\hline $\begin{array}{l}\% \text { Middle } \\
\text { education }\end{array}$ & $28 \%$ & $33 \%$ & $30 \%$ & $32 \%$ & $30 \%$ & $36 \%$ \\
\hline $\begin{array}{l}\% \text { High } \\
\text { education }\end{array}$ & $31 \%$ & $33 \%$ & $32 \%$ & $33 \%$ & $32 \%$ & $37 \%$ \\
\hline $\begin{array}{l}\text { Confidence in } \\
\text { professional } \\
\text { help (average; } \\
\text { range } 1-5 \text { ) }\end{array}$ & 3.7 & 3.9 & 3.8 & 3.9 & 3.8 & 4.0 \\
\hline $\begin{array}{l}\text { Confidence in } \\
\text { lay help } \\
\text { (average; } \\
\text { range 1-5) }\end{array}$ & 3.0 & 2.9 & 3.0 & 2.9 & 3.0 & 2.7 \\
\hline $\begin{array}{l}\text { Confidence in } \\
\text { self-help } \\
\text { (average; } \\
\text { range 1-5) }\end{array}$ & 2.1 & 1.9 & 2.1 & 2.0 & 2.1 & 2.0 \\
\hline \multicolumn{7}{|l|}{ Personality } \\
\hline $\begin{array}{l}\text { Neuroticism } \\
\text { (average; } \\
\text { range 16-59) }\end{array}$ & 39.1 & 41.2 & 39.6 & 41.0 & 40.0 & 42.5 \\
\hline $\begin{array}{l}\text { Extraversion } \\
\text { (average; } \\
\text { range 15-54) }\end{array}$ & 35.2 & 34.8 & 35.0 & 35.0 & 35.1 & 34.2 \\
\hline $\begin{array}{l}\text { Agreeableness } \\
\text { (average; } \\
\text { range 27-58) }\end{array}$ & 42.9 & 42.7 & 42.7 & 42.8 & 42.8 & 42.6 \\
\hline $\begin{array}{l}\text { Openness } \\
\text { (average; } \\
\text { range 12-48) }\end{array}$ & 31.0 & 31.2 & 31.3 & 30.9 & 31.1 & 31.3 \\
\hline $\begin{array}{l}\text { Consciousness } \\
\text { (average; } \\
\text { range 17-54) }\end{array}$ & 36.7 & 36.7 & 36.5 & 36.8 & 36.8 & 35.6 \\
\hline $\begin{array}{l}\text { Evaluation } \\
\text { provider's } \\
\text { emotional } \\
\text { support }\end{array}$ & 2.9 & 3.2 & 2.9 & 3.2 & 3.1 & 3.1 \\
\hline
\end{tabular}


Verhaak, P.F.M., Prins, M.A., Spreeuwenberg, P., Draisma, S., Balkom, T.J.L.M. van, Bensing, J.M., Laurant, M.G.H., Marwijk, H.W.J. van, Meer, K. van der, Penninx, B.W.J.H. Receiving treatment for common mental disorders. General Hospital Psychiatry: 2009, 31(1), 46-55

nivel

\begin{tabular}{|c|c|c|c|c|c|c|}
\hline & \multicolumn{2}{|c|}{$\begin{array}{l}\text { Receiving any } \\
\text { treatment }\end{array}$} & \multicolumn{2}{|c|}{$\begin{array}{l}\text { Receiving treatment in } \\
\text { primary care setting }\end{array}$} & \multicolumn{2}{|c|}{$\begin{array}{l}\text { Receiving treatment in } \\
\text { specialized mental } \\
\text { care setting }\end{array}$} \\
\hline & No & Yes & No & Yes & No & Yes \\
\hline \multicolumn{7}{|l|}{$\begin{array}{l}\text { (average; } \\
\text { range 1-4) }\end{array}$} \\
\hline $\begin{array}{l}\text { Evaluation } \\
\text { patient } \\
\text { centeredness' } \\
\text { (average; } \\
\text { range 1-4 ) }\end{array}$ & 3.0 & 3.4 & 3.1 & 3.4 & 3.2 & 3.4 \\
\hline $\begin{array}{l}\text { Evaluation } \\
\text { provider } \\
\text { quality of care } \\
\text { (average; } \\
\text { range 1-4) }\end{array}$ & 2.8 & 3.0 & 2.9 & 3.0 & 2.9 & 3.1 \\
\hline $\begin{array}{l}\text { Evaluation } \\
\text { information } \\
\text { and advice } \\
\text { (average; } \\
\text { range 1-4) }\end{array}$ & 3.1 & 3.2 & 3.1 & 3.3 & 3.1 & 3.3 \\
\hline $\begin{array}{l}\text { Evaluation } \\
\text { advice self- } \\
\text { help (average; } \\
\text { range 1-4) }\end{array}$ & 2.8 & 3.1 & 2.8 & 3.1 & 3.0 & 3.1 \\
\hline \multicolumn{7}{|c|}{ Enabling characteristics } \\
\hline $\begin{array}{l}\% \text { Household } \\
\text { income } \\
<€ 2200 / \text { month }\end{array}$ & $57 \%$ & $56 \%$ & $56 \%$ & $57 \%$ & $57 \%$ & $56 \%$ \\
\hline$\%$ No paid job & $39 \%$ & $39 \%$ & $40 \%$ & $38 \%$ & $38 \%$ & $48 \%$ \\
\hline $\begin{array}{l}\text { Evaluation of } \\
\text { accessibility } \\
\text { (average; } \\
\text { range 1-4) }\end{array}$ & 2.6 & 2.6 & 2.5 & 2.6 & 2.5 & 2.7 \\
\hline$\%$ Very urban & $73 \%$ & $78 \%$ & $73 \%$ & $78 \%$ & $76 \%$ & $75 \%$ \\
\hline \multicolumn{7}{|l|}{ Need } \\
\hline $\begin{array}{l}\text { \% At least one } \\
\text { depressive } \\
\text { disorder }\end{array}$ & $43 \%$ & $71 \%$ & $47 \%$ & $70 \%$ & $57 \%$ & $72 \%$ \\
\hline $\begin{array}{l}\% \text { At least one } \\
\text { anxiety } \\
\text { disorder }\end{array}$ & $84 \%$ & $76 \%$ & $83 \%$ & $75 \%$ & $78 \%$ & $84 \%$ \\
\hline
\end{tabular}


Verhaak, P.F.M., Prins, M.A., Spreeuwenberg, P., Draisma, S., Balkom, T.J.L.M. van, Bensing, J.M., Laurant, M.G.H., Marwijk, H.W.J. van, Meer, K. van der, Penninx, B.W.J.H. Receiving treatment for common mental disorders. General Hospital Psychiatry: 2009, 31(1), 46-55

nivel

\begin{tabular}{|c|c|c|c|c|c|c|}
\hline & \multicolumn{2}{|c|}{$\begin{array}{l}\text { Receiving any } \\
\text { treatment }\end{array}$} & \multicolumn{2}{|c|}{$\begin{array}{l}\text { Receiving treatment in } \\
\text { primary care setting }\end{array}$} & \multicolumn{2}{|c|}{$\begin{array}{l}\text { Receiving treatment in } \\
\text { specialized mental } \\
\text { care setting }\end{array}$} \\
\hline & No & Yes & No & Yes & No & Yes \\
\hline $\begin{array}{l}\text { Severity } \\
\text { depression } \\
\text { (mean IDS; } \\
\text { range 0-66) }\end{array}$ & 24.2 & 29.4 & 25.0 & 29.3 & 26.4 & 31.8 \\
\hline $\begin{array}{l}\text { Severity anxiety } \\
\text { (mean BAl; } \\
\text { range 0-61) }\end{array}$ & 10.7 & 12.6 & 11.0 & 12.7 & 11.9 & 11.4 \\
\hline $\begin{array}{l}\text { Number of } \\
\text { diagnoses } \\
\text { (mean; range } \\
1-5)\end{array}$ & 1.58 & 2.00 & 1.66 & 1.98 & 1.75 & 2.31 \\
\hline $\begin{array}{l}\% \text { of patients } \\
\text { perceiving a } \\
\text { mental health } \\
\text { problem } \\
\text { themselves }\end{array}$ & $75 \%$ & $97 \%$ & $77 \%$ & $97 \%$ & $86 \%$ & $97 \%$ \\
\hline $\begin{array}{l}\text { Number of } \\
\text { somatic } \\
\text { diseases } \\
\text { (mean; range } \\
0-9 \text { ) }\end{array}$ & 0.73 & 0.66 & 0.72 & 0.66 & 0.70 & 0.64 \\
\hline
\end{tabular}

$* P<.05$.

$* * P<.001$.

Table 4. : Results of multilevel regression analysis on receiving any treatment

\begin{tabular}{|l|l|l|l|l|}
\hline & Estimate & S.E. & Significance & \\
\hline $\begin{array}{c}\text { Level 2: general } \\
\text { practitioners }(n=65)\end{array}$ & .02197 & .09428 & ns & \\
\hline Level 1: patient $(n=743)$ & 1.003 & .06244 & & Step 2 \\
\hline & Step 1 & Odds ratio & $\begin{array}{c}\text { 95\% } \\
\text { confidence } \\
\text { interval }\end{array}$ \\
\hline & $\begin{array}{c}\text { Odds } \\
\text { ratio }\end{array}$ & $\begin{array}{c}\text { 95\% } \\
\text { confidence } \\
\text { interval }\end{array}$ & & \\
\hline Predisposing characteristics & \multicolumn{2}{|l|}{} & & \\
\hline
\end{tabular}


Verhaak, P.F.M., Prins, M.A., Spreeuwenberg, P., Draisma, S., Balkom, T.J.L.M. van, Bensing, J.M., Laurant, M.G.H., Marwijk, H.W.J. van, Meer, K. van der, Penninx, B.W.J.H. Receiving treatment for common mental disorders. General Hospital Psychiatry: 2009, 31(1), 46-55

\begin{tabular}{|l|l|l|l|l|}
\hline & Estimate & S.E. & Significance & \\
\hline Age & .96 & $.94-.99$ & .95 & $.93-.98$ \\
\hline Confidence in professional help & 1.18 & $.82-1.70$ & 1.35 & $.89-2.05$ \\
\hline Personality: neuroticism & 1.04 & $1.00-1.09$ & .98 & $.93-1.04$ \\
\hline $\begin{array}{l}\text { Evaluation provider's emotional } \\
\text { support (average) }\end{array}$ & 1.44 & $1.04-2.00$ & 1.52 & $1.09-2.19$ \\
\hline $\begin{array}{l}\text { Evaluation patient } \\
\text { centeredness }\end{array}$ & 2.56 & $1.43-4.58$ & 2.42 & $1.27-4.60$ \\
\hline $\begin{array}{l}\text { Evaluation provider quality of } \\
\text { care }\end{array}$ & .55 & $.31-.98$ & .55 & $.29-1.03$ \\
\hline Evaluation advice self-help & 1.21 & $.81-1.80$ & 1.35 & $.87-2.09$ \\
\hline
\end{tabular}

\section{Enabling characteristics}

None of the enabling characteristics made a significant difference at univariate level

\begin{tabular}{|c|c|c|}
\hline \multicolumn{3}{|l|}{ Need } \\
\hline $\begin{array}{l}\text { At least one depressive } \\
\text { disorder (no=ref) }\end{array}$ & 1.56 & $.65-3.77$ \\
\hline Severity depression & 1.03 & $.99-1.07$ \\
\hline Severity anxiety & 1.01 & $.98-1.04$ \\
\hline Number of diagnoses & 1.19 & $.74-1.92$ \\
\hline $\begin{array}{l}\text { Patient perceives a mental } \\
\text { health problem him/herself } \\
\text { (no=ref) }\end{array}$ & 11.63 & $3.16-42.9$ \\
\hline
\end{tabular}

Figure in italics: $P<.05$.

Table 5.: Results of multilevel regression on receiving treatment in the primary care setting

\begin{tabular}{|l|l|l|l|l|l|l|}
\hline & Estimate & S.E. & Significance & & & \\
\hline $\begin{array}{l}\text { Level 2: } \\
\text { general } \\
\text { practitioners } \\
(n=65)\end{array}$ & 0 & 0 & ns & & & \\
\hline $\begin{array}{l}\text { Level 1: patient } \\
(n=743)\end{array}$ & 1.003 & .08202 & & & Step 3 \\
\hline & Step 1 & Step 2 & & \\
\hline
\end{tabular}


Verhaak, P.F.M., Prins, M.A., Spreeuwenberg, P., Draisma, S., Balkom, T.J.L.M. van, Bensing, J.M., Laurant, M.G.H., Marwijk, H.W.J. van, Meer, K. van der, Penninx, B.W.J.H. Receiving treatment for common mental disorders. General Hospital Psychiatry: 2009, 31(1), 46-55

nivel

\begin{tabular}{|l|l|l|l|l|l|l|}
\hline & Estimate & S.E. & Significance & & \\
\hline & \multicolumn{2}{|l|l|}{} & & \\
\hline & $\begin{array}{c}\text { Odds } \\
\text { ratio }\end{array}$ & $\begin{array}{c}95 \% \\
\text { confidenc } \\
\text { e interval }\end{array}$ & Odds ratio & $\begin{array}{c}95 \% \\
\text { confidenc } \\
\text { e interval }\end{array}$ & $\begin{array}{c}\text { Odds } \\
\text { rati } \\
\text { o }\end{array}$ & $\begin{array}{c}95 \% \\
\text { confidenc } \\
\text { e interval }\end{array}$ \\
\hline
\end{tabular}

\section{Predisposing characteristics}

\begin{tabular}{|l|l|l|l|l|l|l|}
\hline Age & .98 & $.97-.99$ & .96 & $.94-.98$ & .95 & $.94-.97$ \\
\hline $\begin{array}{c}\text { Personality: } \\
\text { neuroticism }\end{array}$ & 1.01 & $.99-1.03$ & 1.01 & $.98-1.05$ & .97 & $.92-1.01$ \\
\hline $\begin{array}{c}\text { Evaluation } \\
\text { provider's } \\
\text { emotional } \\
\text { support } \\
\text { (average) }\end{array}$ & & & 1.63 & $1.16-2.29$ & 1.64 & $1.37-1.96$ \\
\hline $\begin{array}{c}\text { Evaluation patient } \\
\text { centeredness }\end{array}$ & & & 1.56 & $.92-2.29$ & 1.53 & $.87-2.67$ \\
\hline $\begin{array}{c}\text { Evaluation advice } \\
\text { self-help }\end{array}$ & & & 1.32 & $.91-1.91$ & 1.52 & $1.24-1.85$ \\
\hline $\begin{array}{c}\text { Evaluation } \\
\text { information and } \\
\text { advice }\end{array}$ & & .66 & $.39-1.11$ & .62 & $.35-1.10$ \\
\hline
\end{tabular}

\section{Enabling characteristics}

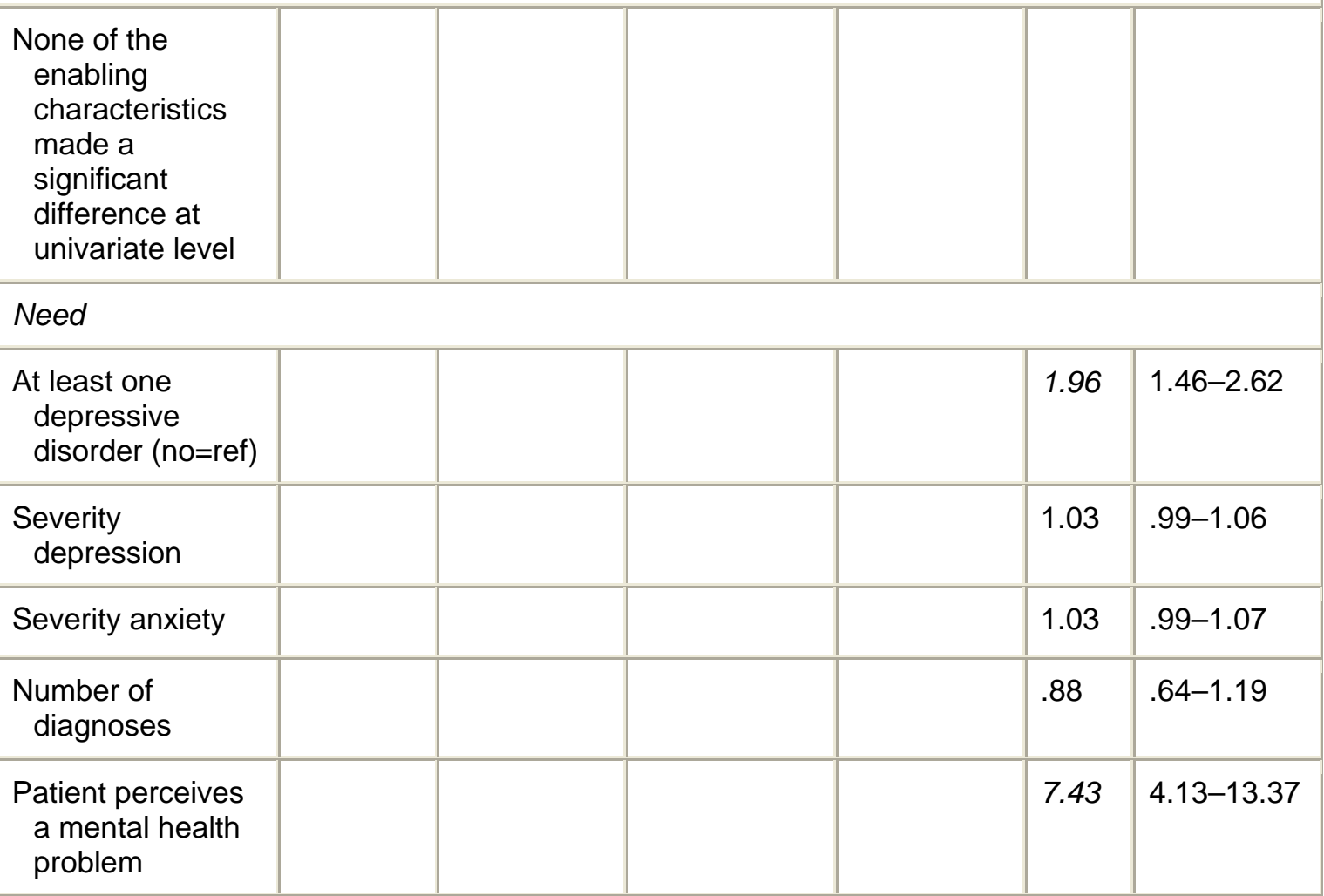


Verhaak, P.F.M., Prins, M.A., Spreeuwenberg, P., Draisma, S., Balkom, T.J.L.M. van, Bensing, J.M., Laurant, M.G.H., Marwijk, H.W.J. van, Meer, K. van der, Penninx, B.W.J.H. Receiving treatment for common mental disorders. General Hospital Psychiatry: 2009, 31(1), 46-55

\begin{tabular}{|l|l|l|l|l|l|l|}
\hline & Estimate & S.E. & Significance & & & \\
\hline $\begin{array}{l}\text { himself/herself } \\
\text { (no=ref) }\end{array}$ & & & & & & \\
\hline
\end{tabular}

Figure in italics: $P<.05$.

Table 6.: Results of multilevel regression analyses on receiving treatment in the specialized mental care setting

\begin{tabular}{|c|c|c|c|c|}
\hline \\
\hline & Estimate & S.E. & Significance & \\
\hline $\begin{array}{l}\text { Level 2: general } \\
\text { practitioners }(n=65)\end{array}$ & 0 & 0 & ns & \\
\hline \multirow[t]{3}{*}{ Level 1: patient $(n=743)$} & 1.062 & .0635 & & \\
\hline & \multicolumn{2}{|l|}{ Step 1} & \multicolumn{2}{|l|}{ Step 2} \\
\hline & $\begin{array}{l}\text { Odds } \\
\text { ratio }\end{array}$ & $\begin{array}{l}95 \% \\
\text { confidence } \\
\text { interval }\end{array}$ & Odds ratio & $\begin{array}{l}95 \% \\
\text { confidence } \\
\text { interval }\end{array}$ \\
\hline \multicolumn{5}{|l|}{ Predisposing characteristics } \\
\hline Confidence in professional help & 1.54 & $1.04-2.30$ & 1.73 & $1.16-2.58$ \\
\hline Confidence in lay help & .71 & $.54-.94$ & .73 & $.54-.98$ \\
\hline Personality: neuroticism & 1.06 & $1.03-1.10$ & 1.01 & $.96-1.06$ \\
\hline \multicolumn{5}{|l|}{ Enabling characteristics } \\
\hline \multicolumn{5}{|l|}{$\begin{array}{l}\text { None of the enabling } \\
\text { characteristics made a } \\
\text { significant difference at } \\
\text { univariate level }\end{array}$} \\
\hline \multicolumn{5}{|l|}{ Need } \\
\hline $\begin{array}{l}\text { At least one depressive } \\
\text { disorder (no=ref) }\end{array}$ & & & .91 & $.40-2.04$ \\
\hline $\begin{array}{l}\text { At least one anxiety disorder } \\
\text { (no=ref) }\end{array}$ & & & 1.14 & $.42-3.06$ \\
\hline Severity depression & & & 1.02 & $.99-1.06$ \\
\hline Number of diagnoses & & & 1.47 & $1.01-2.13$ \\
\hline Patient perceives a mental & & & 3.78 & $.81-17.55$ \\
\hline
\end{tabular}


Verhaak, P.F.M., Prins, M.A., Spreeuwenberg, P., Draisma, S., Balkom, T.J.L.M. van, Bensing, J.M., Laurant, M.G.H., Marwijk, H.W.J. van, Meer, K. van der, Penninx, B.W.J.H. Receiving treatment for common mental disorders. General Hospital Psychiatry: 2009, 31(1), 46-55

\begin{tabular}{|l|l|l|l|l|}
\hline & Estimate & S.E. & Significance & \\
\hline $\begin{array}{l}\text { health problem him/herself } \\
\text { (no=ref) }\end{array}$ & & & & \\
\hline
\end{tabular}

Figure in italics: $P<.05$. 